Departement für Nutztiere der Vetsuisse-Fakultät

Universität Zürich

Klinik für Fortpflanzungsmedizin

(Direktor: Prof. Dr. W. Kähn)

Department of Large Animal Clinical Sciences

Virginia-Maryland Regional College of Veterinary Medicine, USA

Production Management Medicine Section

(Prof. Dr. R. Kasimanickam and Prof. Dr. W.D. Whittier)

Arbeit unter Leitung von Prof. Dr. R. Kasimanickam

\title{
Fixed-time AI pregnancy rate following insemination with frozen-thawed or fresh-extended semen in progesterone supplemented CO-Synch protocol in beef cows
}

\author{
INAUGURAL-DISSERTATION \\ Zur Erlangung der Doktorwürde \\ der Vetsuisse-Fakultät \\ Universität Zürich \\ vorgelegt von \\ Andreas Bucher \\ Tierarzt \\ von Neuenkirch/LU \\ genehmigt auf Antrag von \\ Prof. Dr. W. Kähn, Referent \\ Prof. Dr. R. Kasimanickam, Korreferent
}

Zürich 2009 

1. Summary 1

2. Zusammenfassung 3

3. Résumé 5

4. Introduction 7

5. Material and Methods 9

5.1. Semen handling 9

5.2. Synchronization protocol for fixed-time AI $\quad 10$

$\begin{array}{ll}\text { 5.3. Pregnancy determination } & 12\end{array}$

$\begin{array}{ll}\text { 5.4. Statistical analyses } & 12\end{array}$

6. Results 13

$\begin{array}{ll}\text { 7. Discussion } & 17\end{array}$

8. References 19 



\title{
Fixed-time AI pregnancy rate following insemination with frozen-thawed or fresh-extended semen in progesterone supplemented CO-Synch protocol in beef cows
}

\author{
A. Bucher ${ }^{\mathrm{a}}$, R. Kasimanickamª, J.B. Hall ${ }^{\mathrm{b}}$, J.M. DeJarnette ${ }^{\mathrm{c}}$, W.D. Whittier ${ }^{\mathrm{a}}$, W. \\ $\mathrm{Kähn}^{\mathrm{d}}, \mathrm{Z} . \mathrm{Xu}^{\mathrm{e}}$ \\ ${ }^{\text {a }}$ Department of Large Animal Clinical Sciences, Virginia-Maryland Regional \\ College of Veterinary Medicine, USA \\ ${ }^{\mathrm{b}}$ Department of Animal and Poultry Sciences, College of Agricultural and Life \\ Sciences, Virginia Polytechnic \\ Institute and State University, Blacksburg, VA 24061, USA \\ ${ }^{\text {c }}$ Select Sires Inc., Plain City, OH 43064, USA \\ ${ }^{\mathrm{d}}$ Clinic of Reproductive Medicine, Vetsuisse Faculty, University of Zurich, \\ Switzerland \\ ${ }^{\mathrm{e}}$ Livestock Improvement Corporation, Newstead, Hamilton, New Zealand
}

\section{Summary}

The objective of this study was to compare fixed-time AI pregnancy rate in Angus crossbred beef cows inseminated with frozen-thawed or fresh-extended semen. Two ejaculates from each of two Angus bulls were collected by artificial vagina and pooled for each bull. The pooled semen from each bull was divided into two aliquots; Aliquot 1 was extended using Caprogen ${ }^{\circledR}$ (LIC, Hamilton, New Zealand) to a concentration of $3 \times 10^{6} \mathrm{sperm} / \mathrm{straw}$ and Aliquot 2 was extended using egg-yolk-glycerol extender to a concentration of $20 \times 10^{6} \mathrm{sperm} / \mathrm{straw}$. Semen extended with Caprogen ${ }^{\circledR}$ was maintained at ambient temperature and semen extended with egg-yolk-glycerol extender was frozen and maintained at $-196^{\circ} \mathrm{C}$ until insemination. In each of two breeding seasons (Fall 2007 and Spring 2008), Angus-cross beef cows $(N=1455)$ at 12 locations were randomly assigned 
within location to semen type [Fresh $(N=736)$ vs. Frozen $(N=719)]$ and sire [1 $(N=731)$ vs. $2(N=724)]$. All cows were synchronized with $100 \mu \mathrm{g}$ of $\mathrm{GnRH}$ im and a progesterone Controlled Internal Drug Release insert (CIDR) on Day 0, and on Day 7, $25 \mathrm{mg}$ of PGF $2_{\alpha}$ im and CIDR removal. All cows received $100 \mu \mathrm{g}$ of $\mathrm{GnRH}$ im and were inseminated at a fixed-time on Day 10, $66 \mathrm{~h}$ after CIDR removal. Timed-AI pregnancy rates were influenced by season $(P<0.05)$, cows detected in estrus prior to and at AI $(P<0.001)$, and dam age $(P<0.01)$. Pregnancy rates were not affected by semen type $($ Fresh $=51.5 \%$ vs. Frozen $=$ $50.4 \% ; P=0.66)$ and there were no significant interactions of semen type by estrus expression, semen type by sire, or semen type by season $(P>0.1)$. In conclusion, commercial beef cows inseminated with fresh-extended semen $(3 \times$ $10^{6} \mathrm{sperm} / \mathrm{straw}$ ) yielded comparable pregnancy rates to conventional frozenthawed semen in a progesterone supplemented, CO-Synch fixed-time AI synchronization protocol and may provide an alternative to frozen semen for more efficient utilization of superior genetics.

Keywords: Beef cows; Estrus synchronization; Fresh semen; Frozen semen; Pregnancy rate 


\title{
2. Zusammenfassung
}

\author{
Konzeptionsrate bei Fleischrindern nach blinder, künstlicher Besamung \\ mit Gefrier- oder Frischsamen unter Verwendung eines \\ Brunstsynchronisationsprotokolls (CO-Synch protocol) mittels \\ progesteronabgebender Spirale
}

Das Ziel der vorliegenden Studie bestand im Vergleich der Konzeptionsraten von Angus Kreuzungskühen unter Verwendung von Gefrier- oder Frischsamen.

Je zwei Ejakulate von zwei Angus Stieren wurden mittels künstlicher Vagina gewonnen und für jeden Stier gepoolt. Der gepoolte Samen jedes Stieres wurde in zwei Aliquote geteilt. Das erste Aliquot wurde mit Caprogen (LIC, Hamilton, Neuseeland) zu einer Konzentration von 3 x $10^{6}$ Spermien/Paillette verdünnt. Das zweite Aliquot wurde mit einem Eigelb-Glycerol-Verdünner auf eine Konzentration von $20 \times 10^{6}$ Spermien/Paillette verdünnt. Bis zum Besamungstag wurde der verdünnte Caprogen-Samen bei Zimmertemperatur aufbewahrt. Der verdünnte Eigelb-Glycerol-Samen hingegen bei -196 Grad C tiefgefroren . In beiden Abkalbesaisons (Herbst 2007 und Frühling 2008) wurden die Angus Kreuzungstiere $(\mathrm{N}=1455)$ von 12 verschiedenen Betrieben auf jedem Betrieb nach Zufallskriterien einem Samentyp [Fresh $(n=736)$ vs. Frozen $(n=719)]$ und einem Stier $[1(\mathrm{n}=731)$ vs. $2(\mathrm{n}=724)]$ zugeteilt. Am Tag 0 des Programmes wurden allen Kühen $100 \mu \mathrm{g}$ GnRH i.m. injiziert und und eine ProgesteronSpirale (CIDR) intravaginal appliziert.. Am 7. Tag wurde die Progesteron-Spirale entfernt und 25mg PGF2 2 i.m. appliziert. Am 10. Tag erhielten alle Tiere 100ug GnRH i.m. und wurden genau 66 Stunden nach Spiralenentfernung blind besamt. Die Konzeptionsrate nach blinder, künstlicher Besamung wurde durch die Faktoren Jahreszeit $(\mathrm{P}<0.05)$, Kühe beobachtet in Brunst vor und während der künstlichen Besamung $(\mathrm{P}<0.001)$ und Tieralter $(\mathrm{P}<0.01)$ beeinflusst. Die Konzeptionsrate wurde nicht vom Samentyp $($ Fresh $=51.5 \%$ vs. Frozen $=50.4 \%$; 
$\mathrm{P}=0.66)$ beeinträchtigt. Es konnten keine signifikanten Wechselbeziehungen zwischen Samentyp und Brunstäusserung, Samentyp und Stierenwahl und Samentyp und Jahreszeit erkannt werden $(\mathrm{P}>0.1)$. Unter Verwendung des beschriebenen Brunstsynchronisationsprogrammes (CO-Synch Protokoll) kann zusammenfassend gesagt werden, dass Fleischrinder, die mit Frischsamen (3 x $10^{6}$ Spermien/Paillete) besamt wurden vergleichbare Konzeptionsraten erreichen wie Fleischrinder nach konventioneller Tiefgefrierbesamung. Frischsamen könnte in Zukunft durch die effizientere Nutzung wertvoller Genetik eine Alternative zum Gefriersamen darstellen. 


\section{Résumé}

\section{Comparaison des taux de gestation en semence congelée ou en semence fraiche diluée après insémination artificielle synchronisée (protocole CO- Synch complémenté à la progestérone) sur des vaches allaitantes}

L'objectif de cette étude était de comparer le taux de gestation après insémination à date fixe chez la race Angus crossbeef en utilisant une semence congelée ou fraiche diluée. Deux éjaculats étaient prélevés à deux reprises sur deux taureaux Angus à l'aide d'un vagin artificiel et mis en commun pour chaque taureau. Le mélange pour chaque taureau était ensuite séparé en deux lots. Le lot 1 était dilué en utilisant le diluant Caprogen ${ }^{\circledR}$ (LIC Hamilton, New Zealand) à une concentration de $3 \times 10^{6}$ spermatozoïdes par paillette. Le lot 2 était mélangé à un diluant à base de jaune d'œuf et de glycérol à une concentration de $20 \times 10^{6}$ spermatozoïdes par paillette. Chaque dose était congelée à $-196^{\circ} \mathrm{C}$ jusqu'à insémination. Au cours de deux saisons de reproduction (automne 2007 et printemps 2008), chaque vache Angus cross ( $\mathrm{N}=1455)$, était inséminée de manière aléatoire au sein de chacune des 12 exploitations avec un type de semence [Frais $(\mathrm{n}=736)$ ou Congelé $(\mathrm{n}=719)]$ et avec un des deux taureaux $\left[\mathrm{n}^{\circ} 1\right.$ $(n=731)$ ou $\left.n^{\circ} 2(n=724)\right]$. Toutes les vaches étaient synchronisées avec le même protocole: Administration de $100 \mu \mathrm{g}$ de GnRH IM et pose d'un implant de progestérone à $\mathrm{J}_{0}$. A $\mathrm{J}_{7}$, administration de $7,25 \mathrm{mg}$ de $\mathrm{PGF} 2_{\alpha}$ IM et retrait de l'implant. Toutes les vaches recevaient $100 \mu \mathrm{g}$ de GnRH IM puis étaient inséminées à $\mathrm{J}_{10}, 66 \mathrm{~h}$ après le retrait de l'implant. Les taux de gestation après insémination artificielle planifiée étaient influencés par la saison $(\mathrm{P}<0,05)$, par les vaches détectées en ostrus avant et à l'IA $(\mathrm{P}<0,001)$ et par l'âge des vaches $(\mathrm{P}<0,01)$. Les taux de gestation n'étaient pas influencés par le type de semence (frais $=51 \%$ contre congelé $50,4 \% ; \mathrm{P}=0,66$ ) et il n'y avait pas d'interaction 
significative entre le type de semence et l'expression des chaleurs, le type de semence et le taureau, ou le type de semence et la saison $(\mathrm{P}>0,1)$. En conclusion, l'insémination des vaches de viande en frais dilué à une dose de $3 \times$ $10^{6}$ spermatozoïdes par paillette autorise un taux de gestation comparable à l'insémination en congelé après synchronisation des chaleurs par un implant à progestérone. Ceci peut constituer une alternative à la semence congelée pour une meilleure utilisation de la semence à haute valeur génétique. 


\section{Introduction}

The establishment of seasonal breeding in New Zealand over several decades led the AI industry there to investigate the use of low sperm numbers per insemination while maintaining fertility. In New Zealand, the AI breeding season is between early September and the end of December, during which more than 4 million inseminations are conducted. Approximately $60 \%$ of the NZ dairy cow population (1.7 million dairy cows) is inseminated during a 2-week interval, which requires an efficient usage of high-demand sires [1]. However, the peak of semen demand is over a 3-week period between late October and early November, when the daily numbers of inseminations are over 80,000 (Livestock Improvement Corporation, NZ, unpublished data). Fresh semen offers the advantages of increased sire utilization, inexpensive storage costs and simple handling in the field, when compared to frozen semen. High-merit bulls are able to record up to 300,000 inseminations per year with fresh semen, over twice as many compared to frozen semen [1-3]. In that regard, an average ejaculate yields approximately 400 frozen semen straws $\left(20 \times 10^{6} /\right.$ straw $)$ compared to 5300 straws $\left(1.5 \times 10^{6} /\right.$ straw $)$ with fresh-extended semen. This reduction in sperm concentration per insemination for fresh-extended semen does not compromise fertility.

In the USA, beef cattle farm size is increasing [4], and herd size and calving percentage are negatively correlated to cost per unit weight of beef produced [5]. In larger farms, intensive fixed-time AI synchronization programs can be adopted to improve reproductive success; this requires insemination of large numbers of cows on a single day. With this trend, there is an opportunity to investigate the possibility of maintaining or improving the reproductive outcome in commercial beef operations using fresh0extended semen with low sperm numbers per insemination, instead of frozen-thawed semen with high sperm 
numbers.

Fixed-time AI synchronization protocols are useful tools to impregnate a high percentage of the herd early in the breeding season. The CO-Synch protocol involves administration of $\mathrm{GnRH}, 7 \mathrm{~d}$ before $\mathrm{PGF}_{\alpha}$ treatment, to induce ovulation and/or to reset ovarian follicular growth, leading to the synchronized development of estrogenic preovulatory follicle(s). The $\mathrm{PGF} 2_{\alpha}$ treatment is to induce lysis of corpus luteum. A second GnRH treatment to induce ovulation of preovulatory follicle(s) is given at AI, approximately $60-72 \mathrm{~h}$ after PGF2 $\alpha$. The addition of progesterone vaginal inserts during the first $7 \mathrm{~d}$ of the synchronization protocol in the CO-Synch protocol, suppress early estrus expression, and induce estrus in anestrous cows [6-8]. Our previous CO-Synch-CIDR study, with an interval of $64 \mathrm{~h}$ between the $\mathrm{PGF}_{\alpha}$ and the second $\mathrm{GnRH}$ treatment, resulted in an acceptable fixed-time AI pregnancy rate [9]. This interval should diminish ovulation of immature, low estrogen-producing follicles, and result in the development of a competent corpus luteum [10,11]. The CO-Synch protocol is a commonly used protocol due to minimal handling and acceptable pregnancy rates; hence, it was used in this study.

In the late 1950s, Shannon modified the standard 20\% egg-yolk-citrate extender for use with liquid semen in ambient $\left(15-21{ }^{\circ} \mathrm{C}\right)$ temperature [12]. Caprogen $^{\circledR}$ extender contains 5\% egg-yolk and catalase. Peroxides are detrimental to sperm which are produced by aromatic-L-amino acid oxidase released by dead sperm [13]. The activity of this enzyme is temperature and substrate dependent. The addition of catalase at temperatures over $5{ }^{\circ} \mathrm{C}$ and the reduction of egg-yolk to $5 \%$ as a substrate of the enzyme significantly reduced $\mathrm{H}_{2} \mathrm{O}_{2}$ concentrations [14]. Caprogen ${ }^{\circledR}$ extender is commonly used in NZ to inseminate cows, using fresh semen at lower concentrations. However, it has not yet been tested in a fixed-time AI program under field conditions in the USA.

The hypothesis of this study was that the pregnancy rates of beef cows in 
commercial operations synchronized with CO-Synch-CIDR protocol would not differ between those inseminated with fresh-extended semen $\left(3 \times 10^{6}\right.$ sperm $)$ maintained at ambient temperature and those inseminated with frozen-thawed semen $\left(20 \times 10^{6}\right.$ sperm $)$.

\section{Materials and methods}

\subsection{Semen handling}

Two mature, Angus bulls, known to be highly fertile, were used in this study. The bulls were housed in a stuff center in Ohio, USA. Prior to initiation of the study, $0.5 \mathrm{~mL}$ semen samples of each sire were obtained weekly for 3 consecutive weeks and tested negative by culture for presence of Mycoplasma sp., according to industry guidelines (Certified Semen Services, Columbia, MO, USA). On collection day in fall 2007, 2 ejaculates were collected serially by artificial vagina and pooled within bull. The pooled semen from each bull was assessed for motility and concentration and then divided into two aliquots. Aliquot one was extended using Caprogen ${ }^{\circledR}$ diluent (LIC, Hamilton, New Zealand) to a concentration of $3 \times 10^{6} \mathrm{sperm} / 0.25 \mathrm{~mL}$ French straw. Fresh semen samples were packaged in $0.25 \mathrm{~mL}$ French straws, specially designed for use with non-frozen semen (IMV Technologies, L’Aigle, France; reference \#006937). Straws were stored in Styrofoam boxes at ambient temperature until insemination. Aliquot two was extended using an egg-yolk-glycerol extender to a concentration of $20 \times 10^{6}$ sperm $/ 0.5 \mathrm{~mL}$ French straw, frozen and stored in liquid nitrogen $\left(-196{ }^{\circ} \mathrm{C}\right)$. Semen straws were shipped from the stud center to the breeding locations and cows were artificially inseminated within $48 \mathrm{~h}$ after collection. To meet the stud center standard, fresh semen samples were evaluated each morning to confirm sufficient maintenance of motility $(\geq 60 \%)$ and acrosomal integrity ( $\geq 70 \%$ ) prior to use in AI. Frozen semen was assessed for post-thaw motility after 0 and $3 \mathrm{~h}$ of incubation at $37{ }^{\circ} \mathrm{C}(>60$ and $>25 \%$, 
respectively) and for the percentage of intact acrosomal membranes after $3 \mathrm{~h}$ of incubation at $37{ }^{\circ} \mathrm{C}(>60 \%)$. Similar methods were followed during the spring 2008 breeding season. All fresh and frozen samples passed all evaluations, with the exception of the frozen semen sample of Sire 2 in the spring of 2008. This frozen sample was rejected and a substitute collection meeting the above criteria was used for AI with this sire in the spring of 2008. Otherwise, all other fresh and frozen semen samples used for AI in this study were split-ejaculates.

\section{Table 1}

Mean ( \pm S.E.M.) cow age, body condition scores, days post-calving at protocol initiation for the locations

\begin{tabular}{ccccc}
\hline Location & No. & Age (years) & $\begin{array}{c}\text { Body Condition } \\
\text { Score } \\
\text { (range, } 0-9)\end{array}$ & $\begin{array}{c}\text { Days post-calving at } \\
\text { protocol initiation }\end{array}$ \\
1 & 174 & $4.86 \pm 0.21^{\mathrm{bc}}$ & $5.21 \pm 0.06^{\mathrm{c}}$ & $73.6 \pm 0.92^{\mathrm{ab}}$ \\
2 & 71 & $3.90 \pm 0.22^{\mathrm{c}}$ & $5.20 \pm 0.13^{\mathrm{c}}$ & $79.0 \pm 1.12^{\mathrm{a}}$ \\
3 & 316 & $4.03 \pm 0.11^{\mathrm{c}}$ & $6.15 \pm 0.04^{\mathrm{ab}}$ & $71.1 \pm 1.10^{\mathrm{b}}$ \\
4 & 96 & $5.43 \pm 0.22^{\mathrm{b}}$ & $6.18 \pm 0.08^{\mathrm{a}}$ & $78.5 \pm 1.54^{\mathrm{a}}$ \\
5 & 42 & $3.21 \pm 0.06^{\mathrm{d}}$ & $5.95 \pm 0.14^{\mathrm{ab}}$ & $78.4 \pm 1.44^{\mathrm{a}}$ \\
6 & 43 & $6.26 \pm 0.47^{\mathrm{a}}$ & $5.72 \pm 0.13^{\mathrm{bc}}$ & $64.5 \pm 1.55^{\mathrm{c}}$ \\
7 & 29 & $6.69 \pm 0.54^{\mathrm{a}}$ & $6.24 \pm 0.12^{\mathrm{a}}$ & $67.7 \pm 2.33^{\mathrm{bc}}$ \\
8 & 346 & $5.39 \pm 0.13^{\mathrm{b}}$ & $6.01 \pm 0.89^{\mathrm{ab}}$ & $67.0 \pm 0.85^{\mathrm{bc}}$ \\
9 & 99 & $5.38 \pm 0.23^{\mathrm{b}}$ & $5.99 \pm 1.43^{\mathrm{ab}}$ & $76.3 \pm 0.06^{\mathrm{ab}}$ \\
10 & 98 & $6.17 \pm 0.57^{\mathrm{a}}$ & $5.96 \pm 1.56^{\mathrm{ab}}$ & $75.7 \pm 1.01^{\mathrm{ab}}$ \\
11 & 96 & $4.48 \pm 0.21^{\mathrm{bc}}$ & $6.03 \pm 0.08^{\mathrm{ab}}$ & $74.7 \pm 1.04^{\mathrm{ab}}$ \\
12 & 45 & $5.49 \pm 0.41^{\mathrm{b}}$ & $5.93 \pm 0.13^{\mathrm{ab}}$ & $72.9 \pm 1.41^{\mathrm{ab}}$ \\
\hline
\end{tabular}

Within a column, values without a common superscript differed $(P<0.05)$. Locations 2,4 , 9 , and 10 were fall herds. Locations 1, 5, 7, 11, and 12 were spring herds. Locations 3 and 8 were fall and spring herds.

\subsection{Synchronization protocol for fixed-time AI}

Postpartum Angus crossbred cows $(N=1455)$ that calved in the fall $2007(N=714)$ and spring $2008(N=741)$ at 12 locations (Table 1) within the 
Virginia Department of Corrections, were randomly assigned within location to sire $[N=2 ; 1(N=731)$ vs. $2(N=724)]$ and semen type (Fresh, $N=736$; Frozen, $N=719$ ). All cows were at a minimum of $30 \mathrm{~d}$ post-calving at the initiation of snchronization with a CO-Synch + CIDR protocol (Fig. 1). Briefly, the cows received $100 \mu \mathrm{g}$ of gonadorelin diacetate tetrahydrate im $\left(\mathrm{GnRH}\right.$; Cystorelin ${ }^{\circledR}$ sterile solution, Merial, Athens, GA, USA) and a Controlled Internal Drug Release insert (CIDR; Eazi-Breed ${ }^{\mathrm{TM}}$ CIDR cattle insert $^{\circledR}$, Pfizer Animal Health, New York, NY, USA) on Day 0. Additionally, body condition scores (BCS) of all cows were recorded on Day 0. On Day 7, the CIDR was removed and $25 \mathrm{mg}$ of dinoprost (PGF2 $2_{\alpha}$; Lutalyse ${ }^{\circledR}$ sterile solution, Pfizer Animal Health, New York, NY, USA) was administered im. All cows received a Kamar ${ }^{\circledR}$ Heatmount detector patch (Kamar, Inc., Steamboat Springs, CO, USA) at CIDR removal, to aid in identification of cows displaying signs of estrus prior to and at AI. Cows were inseminated at a fixed-time on Day 10, 66h after CIDR removal, and received 100 $\mu \mathrm{g}$ of GnRH at this time. Exact times at CIDR insertion (concurrent with the first $\mathrm{GnRH}$ ), at CIDR removal (concurrent with $\mathrm{PGF} 2_{\alpha}$ treatment) and at second $\mathrm{GnRH}$ administration (at fixed-time AI) were recorded. Cows in estrus were recorded in the morning, noon and late afternoon on Day 9, and at the time of AI on Day 10. A cow was designated in estrus if she stood for mounting or had an activated (color change from white to red), lost (with mount marks), or partially activated Kamar. Bulls (for natural service) were introduced $14 \mathrm{~d}$ after timed AI, and maintained for a 45-50 d breeding period. The bull:cow ratio was approximately 1:40. The cows were maintained on grass-legume pastures [predominant species were tall fescue (Festuca arundinacea) and Ladino clover (Trifolium repens), Kentucky blue grass (Poa pratensis)], and some groups had access to free choice grass-legume hay, combined with either corn silage or byproduct feeds. 


\section{Figure 1}

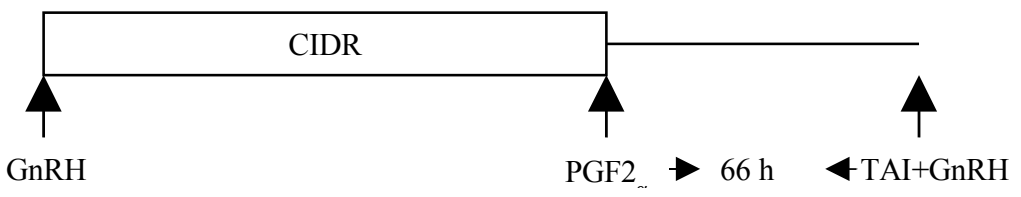

Day 0

Day 7

Day 10

Fig. 1. Schematic representation of the CO-Synch-CIDR protocol: all cows received $100 \mu \mathrm{g}$ of gonadorelin diacetate tetrahydrate $(\mathrm{GnRH})$ im and a Controlled Internal Drug Release insert (CIDR; Eazi-Breed ${ }^{\mathrm{TM}}$ CIDR cattle insert ${ }^{\circledR}$, Pfizer Animal Health, New York, NY, USA) on Day 0. On Day 7, the CIDR was removed and $25 \mu \mathrm{g}$ of dinoprost (PGF2 ${ }_{\alpha}$ ) was administered im. Cows were inseminated at a fixed time on Day 10, $66 \mathrm{~h}$ after CIDR removal and received $100 \mu \mathrm{g} \mathrm{GnRH}$ at AI.

\subsection{Pregnancy determination}

Cows were examined for pregnancy at $57 \mathrm{~d}$ after fixed-time AI by palpation per-rectum and/or transrectal ultrasonography (Sonosite 180 Plus, Sonosite Inc., Bothell, WA, USA) to distinguish AI pregnancy from sire pregnancy. The AI pregnancy rate was estimated by calculating cows diagnosed as pregnant to $\mathrm{AI}$, divided by the total number of cows inseminated.

\subsection{Statistical analyses}

The data were analyzed using a statistical software program (SAS Version 9.1 for Windows, SAS Institute, Cary, NC, USA). General Linear Model procedure was used to evaluate the differences in cow age, body condition score and days post-calving at protocol initiation among locations.

Glimmix model was used to evaluate the effects of semen type, sire, season, age groups ( $2,3-6$ years, $\geq 7$ years), body condition score groups ( $\leq 4,5-6$, $\geq 7$ ), days post-calving groups $(30-60,61-80,>80)$, cows detected in estrus prior 
to and at fixed-time AI, and all two-way interactions, on fixed-time AI pregnancy rates in a manual backward stepwise elimination procedure $(P>0.10$ for exclusion). Locations were considered as random effects. Only variables of interest (sire and semen type) and statistically significant variables were retained in the final model.

\section{Results}

The mean age, body condition score, and days post-calving at protocol initiation among locations were different (Table 1). The mean age, body condition score, days post-calving at protocol initiation and time interval from CIDR insertion and CIDR removal and CIDR removal and fixed-time AI among semen type and sires are shown (Table 2). The mean age of cow between sires and mean days post-calving at protocol initiation between seasons were different.

Accounting for significant variables such as season $(P<0.05)$, cows detected in estrus prior to and at $\mathrm{AI}(P<0.001)$ and age $(P<0.01)$, there was no difference in the AI pregnancy rates between semen types (Fresh $=51.5 \%$ vs. Frozen $=50.4 \% ; P>0.1$; Table 3). No difference in AI pregnancy rates between the two sires (Sire $1=52.1 \%$ vs. Sire $2=49.7 \% ; P>0.1$; Table 3 ). AI pregnancy rates ranged from $46 \%$ to $53 \%$ among age groups. Cows in the $>6$-year age group had the lowest pregnancy rate (45.6\%) compared to the 2-year age group (52.8\%) and 3-6 year age group (52.7\%). Fixed-time AI pregnancy rates were higher in the fall as compared to spring season $(56.3 \%$ vs. $47.9 \%)$. There were no significant interactions for semen type by cows detected in estrus prior to and at $\mathrm{AI}$, semen type by sire and semen type by season $(P>0.1)$.

Fixed-time AI pregnancy rate for Sires 1 and 2 in the frozen semen group was $52.8 \%(180 / 341)$ and $48.1 \%(177 / 368)$, and for Sires 1 and 2 in the fresh semen group was $51.2 \%$ (201/390) and 51.4\% (183/356).

The variance of the location effect for fixed-time AI-PR was estimated as 0.0672 , with an estimated asymptotic standard error of 0.0258 . Based on the 
magnitude of the estimate relative to the standard error, one might conclude that there was significant location-to-location variability. 
Table 2

Mean ( \pm S.E.M.) cow age, body condition score, days post-calving at protocol initiation, interval from CIDR insertion to CIDR removal, the interval from CIDR removal to AI for the semen types, AI sires and seasons.

\begin{tabular}{llllllll}
\hline Variable & Group & No. & Age (years) & $\begin{array}{l}\text { Body } \\
\text { condition } \\
\text { score }\end{array}$ & $\begin{array}{l}\text { Days post-calving } \\
\text { at protocol } \\
\text { initiation }\end{array}$ & $\begin{array}{l}\text { Time from CIDR }{ }^{\mathrm{a}+} \\
\text { GnRH }^{\mathrm{b}} \text { to CIDR } \\
\text { removal }+ \text { PGF2 } \\
\text { (h:min) }\end{array}$ & $\begin{array}{l}\text { Time from } \\
\text { CIDR removal } \\
\text { to AI (h:min) }\end{array}$ \\
\hline Semen type & Fresh & 736 & $4.93 \pm 0.09$ & $5.85 \pm 0.03$ & $73.1 \pm 0.60$ & $172: 54$ & $66: 14$ \\
& Frozen & 719 & $4.92 \pm 0.09$ & $5.96 \pm 0.62$ & $72.9 \pm 0.63$ & $172: 18$ & $66: 56$ \\
Sire & 1 & 731 & $5.12 \pm 0.10 \mathrm{a}$ & $5.93 \pm 0.86$ & $72.8 \pm 0.60$ & $172: 29$ & $66: 28$ \\
& 2 & 724 & $4.69 \pm 0.09 \mathrm{~b}$ & $5.88 \pm 0.03$ & $73.3 \pm 0.36$ & $172: 40$ & $66: 42$ \\
Season & Fall & 714 & $4.76 \pm 0.29$ & $5.99 \pm 0.46$ & $79.2 \pm 0.58 \mathrm{a}$ & $172: 24$ & $66: 26$ \\
& Spring & 741 & $5.08 \pm 0.20$ & $5.82 \pm 0.03$ & $67.1 \pm 0.55 \mathrm{~b}$ & $172: 39$ & $66: 48$ \\
\hline
\end{tabular}

Within variables and between groups, means without a common letter differed $(P<0.05)$.

${ }^{\text {a }}$ CIDR, Controlled Internal Drug Release (intravaginal progesterone insert).

${ }^{\mathrm{b}} \mathrm{GnRH}$-gonadotropin releasing hormone.

${ }^{\mathrm{c}} \mathrm{PGF} 2_{\alpha}-$ prostaglandin $\mathrm{F} 2{ }_{\alpha}$. 


\section{Table 3}

The effect of semen type and sire on the fixed-time AI pregnancy rate in Angus-cross beef $(N=1455)$ cows synchronized with a CO-Synch + CIDR protocol ${ }^{\mathrm{b}}$.

\begin{tabular}{lllll}
\hline Variable & Group & $N$ & Mean PR (95\% CL) & $P$ value \\
\hline Semen type & Fresh (3 million/straw) & 736 & $51.5(47.7,55.1)$ & 0.66 \\
& Frozen (20 million/straw) & 719 & $50.4(46.7,55.7)$ & - \\
\multirow{2}{*}{ Sires } & 1 & & & \\
& 2 & 731 & $52.1(48.5,55.7)$ & 0.36 \\
\hline
\end{tabular}

CL, confidence limits; PR, pregnancy rate; CIDR, Controlled Internal Drug Release (intravaginal progesterone insert).

a Accounted season $(P<0.05)$; cows detected in estrus prior to and at $\mathrm{AI}(P<0.001)$ and dam age $(P<0.01)$; Location considered as a random effect.

${ }^{\mathrm{b}}$ Refer to Fig. 1 for schematic representation of the synchronization protocol. 


\section{Discussion}

The results of this study supported the feasibility of fresh semen usage with a synchronization program under field conditions in the United States. Commercial application of fresh semen in New Zealand is performed under yearround grazing with a confined breeding season, which is similar to conditions in the present study.

In the present study, no difference in the pregnancy rates between fresh semen and frozen semen was detected, even with an $85 \%$ reduction of sperm numbers in the fresh semen $\left(3 \times 10^{6} \mathrm{sperm} / \mathrm{straw}\right)$ as compared to the frozen semen $\left(20 \times 10^{6} \mathrm{sperm} / \mathrm{straw}\right)$. The similarity in pregnancy rates may be attributable to survivability of fresh sperm. With frozen semen, the functional and structural parameters of sperm are impaired after the freeze-thaw process. Therefore, they are less likely either to survive long enough in the female reproductive tract or to maintain competency in fertilization, as compared to fresh-extended semen [14].

Numerous synchronization programs have been developed within the past 20 years. These programs have facilitated the beef producer's ability to utilize a short breeding season. Nevertheless, the increased handling time necessary for synchronization programs and $\mathrm{AI}$ is troublesome for many producers. In a fixedtime AI protocol, the breeding day is the most labor-intensive and timeconsuming day of the process. The use of fresh-semen has not been considered as an advantage for synchronization protocols during their development [15]. Fresh semen has advantages over frozen semen where ovulation asynchrony and frozen sperm longevity are problems. Fresh semen minimizes time and labor necessary on the breeding day, because thawing of frozen semen is not required. The freezethaw process of frozen semen is accompanied by many opportunities for human erro, which lowers semen quality and decreases efficiency of AI. Without question, the greatest advantage of fresh semen resides in increasing utilization efficiency of semen from short-supply and (or) high-demand sires. Fixed-time AI 
in conjunction with fresh semen at reduced sperm concentration and rapid overnight semen delivery may provide an opportunity to dramatically enhance utilization efficiency of both beef and dairy sires that are in high demand and short supply. However, in the absence of improved conception rates of fresh semen over conventional semen, there is little incentive to produce a fresh semen product with a limited shelf-life ( $72 \mathrm{~h})$ from sires that can presently satisfy market demand at conventional cryopreserved sperm dosages and virtually unlimited shelf-life. Although semen supply is seldom an issue in beef breeds, this increased utilization efficiency may have huge implications in dairy breeds.

Ovulation time can influence reproductive success when using either fresh or frozen semen [16]. Insemination with frozen semen $10 \mathrm{~h}$ before projected ovulation decreased conception rate, compared with $5 \mathrm{~h}$ before projected ovulation, which may be due to the shorter capacitation time of frozen semen or increased population of precapacitated frozen sperm [17]. A new follicular wave can emerge from $1 \mathrm{~d}$ prior to $4 \mathrm{~d}$ post-GnRH treatment, which certainly fails to synchronize ovulation at an exact time [18]. Future studies may test the hypothesis that fresh semen's prolonged longevity in the female reproductive tract will compensate for the asynchrony in ovulation in a synchronization program and improve pregnancy rate, if cows are inseminated 36-48 $\mathrm{h}$ after CIDR removal.

In conclusion, fresh-extended semen $\left(3 \times 10^{6}\right.$ sperm/insemination $)$ was successfully utilized in a fixed-time AI synchronization program to achieve comparable pregnancy rates to cryopreserved semen in commercial beef operations under field conditions in the USA. 


\section{References}

[1] Vishwanath R, Pitt CJ, Shannon P. Sperm numbers, semen age and fertility in fresh and frozen bovine semen. Proc N Z Soc Anim Prod 1996;56:31-4.

[2] Macmillan KL, Curnow RJ. Factors influencing A.I. conception rates, XI. Variation in sire fertility. N Z J Exp Agric 1977;5:279-85.

[3] Vishwanath R. Artificial insemination: the state of the art. Theriogenology 2003;59:571-84.

[4] USDA-NASS statistical highlights of US agriculture 2006-2007. http://www.nass.usda.gov/Publications/Statistical_Highlights/2007/tables/liv estock.html.

[5] Ramsey R, Doye D, Ward C, McGrann J, Falconer L, Bevers S. Factors affecting beef cow-herd costs, production, and profits. JAAE 2005;37:91-9.

[6] Geary TW, Whittier JC. Effects of a timed insemination following synchronization of ovulation using the Ovsynch or CO-Synch protocol in beef cows. Prof Anim Sci 1998;14:217-20.

[7] Larson JE, Lamb GC, Stevenson JS, Johnson SK, Day ML, Geary TW, et al. Synchronization of estrus in suckled beef cows for detected estrus and artificial insemination and timed artificial insemination using gonadotropinreleasing hormone, prostaglandin F2alpha, and progesterone. J Anim Sci 2006;84:332-42.

[8] Schafer DJ, Bader JF, Meyer JP, Haden JK, Ellersieck MR, Lucy MC, et al. Comparison of progestin-based protocols to synchronize estrus and ovulation before fixd-time artificial insemination in postpartum beef cows. J Anim Sci 2007;85:1940-5.

[9] Kasimanickam R, Hall JB, Currin JF, Inman B, Rudolph JS, Whittier WD. Pregnancy rates in Angus crossbeef cows bred at observed estrus with or without second GnRH administration in fixed time progesterone 
supplemented Ovsynch and CO-Synch protocols. Reprod Dom Anim Epub Oct 2008; in press.

[10] Perry GA, Smith MF, Lucy MC, Green JA, Parks TE, MacNeil MD, et al. Relationship between follicle size at insemination and pregnancy success. Proc Natl Acad Sci 2005;102:5268-73.

[11] Vasconcelos JM, Sartori R, Oliveira HN, Guenther JG, Wiltbank MC. Reduction in size of the ovulatory follicle reduces subsequent luteal size and pregnancy rate. Theriogenology 2001;56:307-14.

[12]Foote RH. The history of artificial insemination: selected notes and notables. J Anim Sci 2002;80:1-10.

[13] Shannon P, Curson B. Effect of storage temperature on the viability and fertility of bovine sperm diluted and stored in Caprogen. N Z J Agric Res 1984;27:173-7.

[14] Parks JE, Graham JK. Effects of cryopreservation procedures on sperm membranes. Theroigenology 1992;38:209-22.

[15] Vishwanath R, Shannon P. Do sperm cells age? A review of the physiological changes in sperm during storage at ambient temperature. Reprod Fertil Dev 1997;9:321-31.

[16]Macmillan KL, Watson JD. Fertility differences between groups of sires relative to the stage of oestrus at the time of insemination. Anim Prod 1975;21:243-9.

[17] Parrish JJ, Foote RH. Fertility of cooled and frozen rabbit sperm measured by competitive fertilization. Biol Reprod 1986;35:253-7.

[18]Martinez MF, Adams GP, Kastelic JP, Bergfelt DR, Mapletoft RJ. Induction of follicular wave emergence for estrus synchronization and artificial insemination in heifers. Theriogenology 2000;54:757-69. 




\section{Lebenslauf}

Name

Geburtsdatum

Geburtsort

Nationalität

Heimatort

$1986-1992$

$1992-1999$

1999

$2000-2005$

2005

2006

$2006-2007$

$2007-2008$

Seit 2008

20.04.2009
Bucher Andreas

29. Januar 1979

Littau, LU

Schweiz

Littau / Schötz

Primarschule Littauerberg, LU

Kantonsschule Reussbühl, LU

Maturitätsabschluss Typ B

Studium der Veterinärmedizin an der Vetsuisse-Fakultät der Universität Zürich

Staatsexamen an der Vetsuisse-Fakultät der Universität Zürich

Anstellung als Assistenztierarzt in der Nutztierpraxis Indermühle AG, Herzogenbuchsee, BE

Internship, Food Animal Ambulatory/Production Management Medicine, Blacksburg, VA

Assistenztierarzt, Food Animal Ambulatory/ Production Management Medicine, Blacksburg, VA, Beginn Dissertation unter Leitung W. Kähn

Anstellung als Assistenztierarzt in der Nutztierpraxis Indermühle AG, Herzogenbuchsee, BE 